\title{
Pemutusan Penularan Covid-19 melalui Penggunaan Masker, Menjaga Jarak, dan Penggunaan Alat Dispenser Hand Sanitizer
}

\author{
DOI: https://doi.org/10.32509/abdimoestopo.v5i1.1765

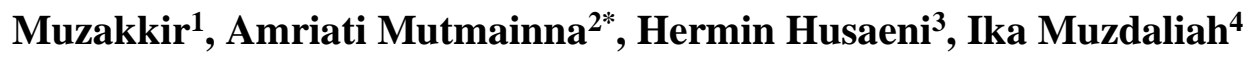 \\ ${ }^{1,2}$ STIKES Nani Hasanuddin Makassar \\ Jl. Perintis Kemerdekaan VIII No.24 Makassar, Sulawesi Selatan 90245 \\ ${ }^{3,4}$ Universitas Sulawesi Barat \\ Jl. Prof. Dr. Baharuddin Lopa, SH, Majene, Sulawesi Barat 91412 \\ *Email Korespondensi: amriatimutmainna29@gmail.com
}

\begin{abstract}
In early 2020 the world was shocked by the emergence of a virus known as 2019 novel coronavirus or abbreviated 2019-nCov which is an infectious disease similar to influenza caused by Severe Acute Respiratory Syndrome Coronavirus 2 (SARS-CoV-2). So it can be concluded that the community service that will be carried out is very giving a good contribution. The target that will be carried out by the community service team is as many as 200 targets. This needs to be considered, especially for people in Majene Regency, West Sulawesi Province. Based on the results of the initial survey conducted by the community service team, the number of people who will be the target of community service is as many as 200 people. The results were the joint interview with the Head of Majene Regency that there is a need for a detailed understanding of the use of masks, maintaining distance, and the use of hand sanitizer dispensers. The community service team is motivated to do community service about breaking the chain of transmission of Covid-19 in the holy month of Ramadan through the use of masks, maintaining distance, and using hand sanitizer dispensers in mosques.
\end{abstract}

Keywords: Covid-19, Use of Hand Sanitizer Dispenser Tool, Use of Masks, Maintain Distance

Abstrak - Pada awal 2020 dunia dikejutkan dengan munculnya virus yang dikenal dengan sebutan 2019 novel coronavirus atau disingkat 2019-nCov yang merupakan penyakit menular yang mirip dengan influenza yang disebabkan oleh Severe Acute Respiratory Syndrome Coronavirus 2 (SARS-CoV-2). Maka bisa disimpulkan bahwa pengabdian masyarakat yang akan dilakukan ini sangat memberikan kontribusi yang baik. Target yang akan dilakukan oleh tim pengabdian masyarakat adalah sebanyak 200 target. Hal ini perlu menjadi hal yang diperhatikan terutama pada masyarakat yang berada di Kabupaten Majene Provinsi Sulawesi Barat. Berdasarkan hasil survei awal yang dilakukan oleh tim pengabdian masyarakat jumlah masyarakat yang akan menjadi target pengabdian masyarakat yaitu sebanyak 200 orang. Hasil wawancara bersama dengan Kepala Kabupaten Majene bahwa perlu adanya pemahaman secara mendetail mengenai penggunaan masker, menjaga jarak, dan penggunaan alat dispenser hand sanitizer. Tim pengabdian masyarakat termotivasi untuk melakukan Pengabdian Masyarakat tentang pemutusan mata rantai penularan Covid-19 bulan suci ramadhan melalui penggunaan masker, menjaga jarak, dan penggunaan alat dispenser hand sanitizer di mesjid.

Kata Kunci: Covid-19, Hand Sanitizer, Penggunaan Masker, Menjaga Jarak 


\section{PENDAHULUAN}

Tren virus corona atau biasa disebut dengan Covid-19 merupakan pandemic yang belum berakhir pada saat ini. Sebagian besar Negara yang ada di dunia melaporkan bahwa lebih sedikit infeksi Covid-19 baru. Namun, hal ini merupakan data secara global yang menunjukkan pula bahwa pandemic belum berakhir. Adapun target dari semua Negara yaitu masuk kedalam bagian nol kasus baru selama emapt minggu berturut-turut atau selama sebulan.

Berdasarkan data yang ada menurut World Health Organization pertanggal 22 April 2021, jumlah kasus Covid-19 terkonfirmasi sebesar 142.557.268 jiwa, selanjutnya dipaparkan pula mengenai jumlah kasus kematian Covid-19 terkonfirmasi sebanyak 3.037.398 jiwa, dan juga disebutkan pula jumlah kasus dengan Negara yang terkonfirmasi Covid-19 sebesar 223 negara (WHO, 2021).

Di Indonesia didapatkan data nasional mengenai summary update yang dikeluarkan oleh Satuan Tugas Penanganan Covid-19 bahwa pada 1 minggu terakhir terjadi penurunan kasus sebesar $-14,2 \%$. Pada pekan ini, terdapat 23 Provinsi yang mengalami kenaikan kasus, 11 Provinsi yang mengalami penurunan kasus. Adapun pada provinsi yang mengalami kenaikan, dengan kenaikan tertinggi terlihat di Jawah Tengah naik 21.3\%, disusul Riau naik 37,6\%, Sulawesi Selatan naik 80.3\%, Jawa Barat naik 4.8\%, dan Sumatera Barat naik 30.6\%. Adapun mengenai top 5 provinsi dengan jumlah kasus terendah, yaitu Maluku Utara sebanyak 4.357 jiwa, selanjutnya Gorontalo sebanyak 5.257 jiwa, kemudian Sulawesi Barat sebanyak 5.387 jiwa, lalu Bengkulu sebanyak 5.795 jiwa, dan terakhir yaitu Kalimantan Barat sebesar 6.410 jiwa (Satuan Tugas Penanganan Covid-19, 2021).

Adapun data tersebut, yang perlu digarisbawahi adalah data yang terdapat pada Provinsi Sulawesi Barat itu sendiri dikarenakan hal ini terkait dengan lokasi pengabdian masyarakat yang akan dilaksanakan pada saat ini. Keadaan yang dialami oleh Provinsi Sulawesi Barat yaitu masih memiliki jumlah kasus sebesar 5.387 jiwa.

Berdasarkan data yang ada di Satgas Penanganan Covid-19 juga terdapat data insiden kumulatif kabupaten atau kota yang ada di Sulawesi Barat, yaitu dibagi menjadi dua bagian, yang pertama jumlah kasus tertinggi dan jumlah kasus terendah. Adapun jumlah kasus tertinggi terdapat pada kabupaten Polewali Mandar sebesar 2.033 kasus, selanjutnya kabupaten mamuju sebanyak 1.470 kasus, da nada pula di kabupaten mamuju utara sebesar 760 kasus. Sedangkan, jumlah kasus terendah terdapat pada kabupaten Mamasa sebesar 159 kasus, lalu kemudian kabupaten mamuju tengah sebanyak 381 kasus, serta kabupaten majene sebesar 584 kasus (Satuan Tugas Penanganan Covid-19, 2021).

Hal ini yang perlu dititikberatkan pada perhatian kita yaitu pada Kabupaten Majene yang dimana dalam pernyataan sebelumnya bahwa Kabupaten Majene terdapat pada kelompok kasus terendah berdasarkan data insiden kumulatif kabupaten atau kota di Sulawesi Barat yang dilakukan oleh Satgas Penanganan Covid-19. Dan juga, Kabupaten Majene ini menjadi hal yang perlu diperhatikan dikarenakan Kabupaten ini merupakan target atau sasaran pengabdian masyarakat yang akan dilaksanakan kali ini.

Langkah penanganan yang dianjurkan oleh pemerintah yaitu menjaga kebersihan, mengenakan masker, dan menjaga jarak. Adapun menjaga kebersihan yang dimaksud dalam hal ini yaitu cuci tangan secara rutin. Selanjutnya, mengenakan masker yang dimaksudkan yaitu masker sebaiknya menutupi hidung dan mulut. Selain itu pula, maksud dan tujuan menjaga jarak yaitu menghindari kontak langsung dengan orang lain agar terhindar dari penularan Covid-19 (infocorona.makassar.go.id, 2021).

Adapun pengabdian masyarakat yang telah dilakukan oleh Irmayani, dkk (2021) menyatakan bahwa edukasi yang diberikan kepada masyarakat pada kegiatan PKM yang dilaksanakannya meliputi pentingnya menjaga jarak minimal 1 meter saat berinteraksi, 
mempraktekkan mengenai cara cuci tangan yang benar, menjelaskan etika batuk dan bersin yang benar serta pentingnya melakukan aktifitas fisik ringan dan konsumsi makanan seimbang. Pemberian edukasi dilakukan secara tatap muka kepada masyarakat (door to door). Komunikasi dilakukan secara interpersonal. Komunikasi yang paling efektif dalam penyampaian pesan dikarenakan komunikasi ini dilakukan secara tatap muka (person to person) sehingga pesan komunikasi dapat diterima dengan mudah oleh penerima pesan. Respon masyarakat terhadap kegiatan ini sangat baik. Masyarakat dengan antusis mendengarkan penjelasan yang diberikan tim PKM.

Berdasarkan latar belakang diatas, maka bisa disimpulkan bahwa pengabdian masyarakat yang akan dilakukan ini sangat memberikan kontribusi yang baik. Sehingga diharapkan dapat memberikan manfaat yang lebih pula bagi masyarakat yang bermitra dengan pelaksanaan pengabdian masyarakat ini.

Berdasarkan hasil survei awal yang dilakukan oleh tim pengabdian masyarakat jumlah masyarakat yang akan menjadi target pengabdian masyarakat yaitu sebanyak 200 orang. Hasil wawancara bersama dengan Kepala Kabupaten Majene bahwa perlu adanya pemahaman secara mendetail mengenai penggunaan masker, menjaga jarak, dan penggunaan alat dispenser hand sanitizer. Berdasarkan latar belakang di atas pula, tim pengabdian masyarakat termotivasi untuk melakukan Pengabdian Masyarakat tentang pemutusan mata rantai penularan Covid-19 bulan suci ramadhan melalui penggunaan masker, menjaga jarak, dan penggunaan alat dispenser hand sanitizer di mesjid.

\section{METODE PELAKSANAAN}

Metode pelaksanaan yang akan dilakukan oleh tim pengabdian masyarakat adalah melakukan evaluasi pemahaman masyarakat khususnya penjelasan mengenai Covid-19, setelah itu tim pengabdian masyarakat melakukan penyuluhan pemakaian masker dengan benar sambil membagikan masker secara gratis, selanjutnya dilakukan simulasi dengan mencuci tangan dengan benar menggunakan alat dispenser hand sanitizer, kemudian menampilkan video menjaga jarak yang benar pula yang selanjutnya dilakukan simulasi menjaga jarak secara langsung.

Rincian materi yang diberikan dimulai dari materi menjelaskan tentang Covid-19 dengan metode penyuluhan. Setelah itu, materi yang diberikan yaitu menjelaskan pemakaian masker dengan benar sambil melakukan simulasi pemakaian masker dengan benar. Pemateri dalam hal ini adalah Bapak Dr. Muzakkir,S.Sit.,M.Kes yang dimana beliau memiliki riwayat kepakaran maupun kompetensi yang memumpuni dibidangnya, terutama dalam bidang pengabdian kepada masyarakat yang dilaksanakan dalam hal ini. Selanjutnya, pemateri menjelaskan mencuci tangan dengan benar menggunakan alat dispenser hand sanitizer kemudian mensimulasikannya. Selain itu pula, pemateri menjelaskan cara menjaga jarak yang benar disertakan pula cara peragaannya. Beliau pulalah yang memiliki solusi dalam memecahkan masalah pengabdian kepada masyarakat ini dengan melakukan sosialisasi pemakaian masker, menjaga jarak, dan penggunaan hand sanitizer ini.

Adapun pembagian masker dan hand sanitizer secara gratis kepada seluruh masyarakat yang berada di tempat dilakukannya pengabdian kepada masyarakat yang dimana telah diperkirakan jumlah yang akan datang yaitu sebanyak 200 orang. Adapun metode yang digunakan dalam pengabdian kepada masyarakat ini yaitu menggunakan data kuantitatif dengan pendekatan cross sectional. Hal ini untuk mengetahui gambaran pemutusan mata rantai penularan covid-19 melalui penggunaan masker, menjaga jarak aman, dan penggunaan alat dispenser hand sanitizer. 


\section{HASIL PENEMUAN DAN DISKUSI}

Berdasarkan dari hasil kegiatan pelaksanaan pengabdian kepada masyarakat yang telah dilakukan oleh tim pengabdian masyarakat yang beranggotakan 9 orang, terdiri dari Ketua Tim, 3 Anggota Tim, dan 5 Mahasiswa yang terlibat didalamnya, maka disimpulkan bahwa hasil yang didapatkan yaitu Kegiatan Pengabdian kepada Masyarakat ini telah dilaksanakan di Masjid di Mesjid Miftahul Medina Lingkungan Salabulo, Kelurahan Tande Timur Kecamatan Banggae Timur. Kegiatan dimulai dengan sesi sosialisasi tentang Situasi Covid19 dan cara pencegahan penularannya, dihadiri oleh 200 orang yang terdiri dari tokoh masyarakat dan masyarakat sekitar. Pada sesi ini juga diadakan diskusi yang bertujuan untuk meningkatkan pemahaman dan menetralisir hoax yang beredar di masyarakat tentang pemahaman bahwa pandemi Covid-19 ini hanya hal yang sengaja diadakan untuk mengurangi aktifitas produktif mereka, yang dengan pemahaman tersebut membuat mereka tidak patuh terhadap protokol kesehatan 3M yang dicanangkan oleh pemerintah.

Menurut Mariroh, dkk (2020) menyatakan bahwa penerapan protokol kesehatan di Kampung Tangguh Semeru Perumahan Mastrip sudah dijalankan dengan baik. Indikator kesadaran masyarakat, portal penjagaan, lumbung pangan, dan bidang kesehatan sudah cukup baik, kelengkapan posko kampung tangguh, bidang keamanan, dan inovasi sudah berjalan dengan baik.

Adapun menurut Nuraeni, dkk (2021) bahwa untuk meningkatkan pengetahuan masyarakat melalui sosialisasi penggunaan masker dan pembagian masker sebanyak 2000 masker kain 3 lapis kepada masyarakat yang berada di Kota Tasikmalaya dan Kabupaten Tasikmalaya yang dilaksanakan pada bulan September 2020. Kegiatan ini berjalan dengan lancar dan tanpa hambatan. Respon masyarakat cukup baik, sangat terbuka dan antusias. Kegiatan ini sangat bermanfaat terutama bagi masyarakat yang beraktivitas di area public seperti pasar dan lapangan olahraga. Kegiatan ini diharapkan berkelanjutan serta perlu adanya monitoring berkala dengan jangkauan yang lebih luas untuk mencegah penyebaran Covid-19.

Menurut Gustini, dkk (2021) menyatakan pula bahwa Coronavirus Disease 2019 (COVID-19) merupakan penyakit menular yang disebabkan oleh Coronavirus jenis baru yang menyebabkan terjadinya wabah di tengah masyarakat. Penanganan dan pencegahan kasus pandemik ini sudah dilakukan dengan berbagai cara, baik secara global maupun nasional atau wilayah akan tetapi penerapan protokol kesehatan seperti penggunaan masker oleh masyarakat dalam pencegahan terinfeksi Covid-19 belum berjalan secara maksimal. Penggunaan Masker sangat penting untuk melindungi pemakainya dari berbagai infeksi atau kemungkinan menularkan infeksi Covid-19. Melihat masih banyaknya masyarakat yang belum menggunakan masker saat berada di tempat umum, maka dosen bersama mahasiswa STIK Indonesia Jaya melakukan kegiatan pengabdian kepada masyarakat melalui pembagian masker untuk mencegah terjadinya penularan Covid-19 di Desa Binangga Kecamatan Marawola Kabupaten Sigi. Kegiatan pembagian masker ini dilakukan pada saat berlangsungnya kegiatan lomba karapan sapi, mengingat banyaknya masyarakat yang mengikuti kegiatan tersebut tetapi tidak menggunakan masker. Hal ini dilakukan secara langsung dengan membagikan masker kepada masyarakat terutama masyarakat yang tidak memiliki dan tidak menggunakan masker di tempat berlangsungnya lomba karapan sapi di Desa Binangga. Kegiatan Pembagian masker dilakukan pada tanggal 22 Maret 2021 kepada 100 orang masyarakat yang tidak memiliki/menggunakan masker. Masyarakat yang diberikan masker menggunakan masker dengan tepat terutama di tempat umum pada saat kegiatan perlombaan karapan sapi berlangsung.

Berdasarkan pengabdaian kepada masyarakat yang dilakukan oleh Lette, dkk (2021) bahwa kegiatan pengabdian ini dilaksanakan di pasar Oesao-Kabupaten Kupang. Total masker dan vitamin yang dibagikan sebanyak 450 paket. Kegiatan pengabdian dapat berjalan 
dengan baik. Pihak pengelola dan kepolisian setempat mendukung kegiatan pengabdian yang dilakukan. Para pedagang mulai sadar dan memakai masker setelah kegiatan pengabdian ini dilakukan walaupun belum semua pedagang menjadi sadar. Komunikasi, Edukasi dan Informasi (KIE) perlu secara berkala diberikan kepada para pedagang karena kesadaran pedagang untuk mematuhi protokol Kesehatan cukup rendah.

Setelah kegiatan sosialisasi, kami lanjutkan kegiatan dengan sesi pembagian masker sebanyak 200 dus yang masing-masing berisi 500 lembar masker 3 ply dan 200 dus hand sanitizer cair yang masing-masing berisis 200 botol. Masker dan hand sanitizer ini diserahkan kepada tokoh masyarakat yang hadir setempat yang nantinya akan mendistribusikannya kepada masyarakat setempat. Hal ini dilakukan untuk mencegah terjadinya kerumunan yang merupakan salah satu cara mencegah penularan Covid-19. Dengan adanya pebagianmasker ini pun dapat menambah pemahaman masyarakat tentang jenis masker dan hand sanitizer yang tepat digunakan dalam rangka penceghan penularan Covid-19.

Menurut Kresna dan Ahyar (2020) bahwa bencana pandemik Covid-19 telah berpengaruh sangat luas dan masif terhadap berbagai dimensi kehidupan masyarakat, baik di bidang hubungan sosial maupun ekonomi dan bisnis, serta kondisi kesehatan masyarakat. Bencana pandemik Covid-19 dan kebijakan pembatasan sosial akhirnya memaksa sebagian besar pelaku masyarakat menguruangi kegiatannya diluar rumah sehingga merubah perilaku masyarakat untuk melakukkan kegiatan baik bekerja maupun belajar secara daring dirumah. Perubahan perilaku masyarakat yang diakibatkan oleh penerapan kebijakan physical distancing dan social distancing merupakan cara terbaik yang dapat dilakukan untuk menghambat penyebaran dan penularan virus Covid-19 ditengah masyarakat.

Upaya-upaya yang dilakukan oleh pemerintah saat melaksanakan kebijakan physical distancing dan social distancing dengan menerapkan protokol-protokol kesehatan yang berlaku dan gencar melakukan sosialisai mengenai penerapan pola hidup sehat. Prakteknya masyarakat dapat menerapkan physical distancing dengan melakukan beberapa cara seperti, tidak meninggalkan rumah kecuali untuk kondisi yang sangat genting seperti membeli kebutuhan pokok atau berobat, menyapa orang lain dengan melambaikan tangan tidak berjabat tangan, rutin melakukan kegiatan olahraga dirumah minimal 30 menit sehari untuk menjaga daya tahan tubuh, memanfaatkan fasilitas gadget yang tersedia dirumah agar tetap dapat bekerja atau belajar dari rumah. Hal ini tentu memiliki dampak yang positif terhadap menjaga kesehatan masyarakat luas. Dengan penerapan protokolprotokol kesehatan dan upaya-upaya yang perlu diperhatikan oleh masyarakat luas untuk selalu menjaga kebersihan dan menerapkan pola hidup sehat sehingga masyarakat terhindar dari bahaya penularan dan dampak gangguan kesehatan dari penularan virus Covid-19. Sehingga dapat disimpulkan bahwa physical distancing dan social distancing memiliki pengaruh yang signifikan terhadap kesehatan (Kresna \& Ahyar, 2020).

Menurut Kandari dan Ohorella (2020) menyatakan pula bahwa anggota Panti Asuhan Al-Faqri telah memahami dan bersedia berperan penting dalam memutus rantai COVID-19 dengan melakukan physical distancing. Kegiatan ini memberikan manfaat kepada mayarakat dengan informasi yang mereka peroleh khususnya pada anak yang membutuhkan perhatian khusus untuk memahami pentingnya memutus rantai COVID-19 dengan physical distancing.

Adapun menurut Isdairi dan Anwar (2021) menyatakan bahwa Kepatuhan Masyarakat dalam menerapkan social distancing di Kabupaten Sambas dapat dilihat dari tigas aspek. Pertama, ketidakpatuhan masyarakat dalam melaksanakan protokol kesehatan tidak hanya dipengaruhi sikap mental yang bersumber dari dalam diri individu masyarakat itu sendiri, tetapi juga ketidakpatuhan masyarakat dipengaruhi oleh adanya kebijakan pemerintah yang tidak konsisten. Kedua, pemahaman masyarakat untuk melaksanakan protokol kesehatan masih rendah, terdapat pemahaman yang salah dalam memaknai new normal, masih rendahnya kepercayaan masyarakat tentang adanya Covid-19, dan sebagian kalangan beragama masih beranggapan bahwa hidup dan mati adalah urusan Tuhan, sehingga enggan untuk menerapkan social distancing saat melakukan ibadah di masjid. Ketiga, sikap kelakuan yang menunjukkan kesungguhan hati untuk mentaati atau mematuhi himbauan pemerintahan 
dalam melaksanakan social distancing masih rendah dan belum adanya payung hukum seperti Peraturan Bupati yang mengatur tentang tindakan kedisiplinan masyarakat dalam mentaati protokol kesehatan. Meski demikian, Pemkab Sambas telah melakukan beberapa upaya untuk mengatasi ketidakpatuhan tersebut melalui pelaksanaan rapid test, sosialisasi, penyusunan draft peraturan bupati, dan melakukan pengetatan perijinan keramaian.

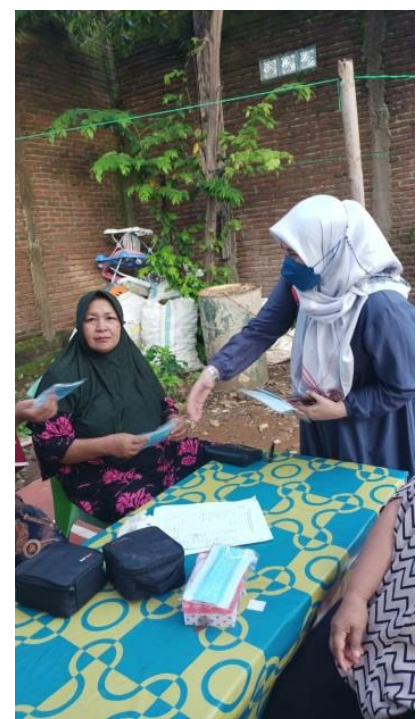

Gambar 1. Dokumentasi Pemberian Masker kepada Masyarakat

Dengan adanya kegiatan ini, masyarakat mengungkapkan mendapat informasi tentang Covid-19 yang dapat dipahami dan diterima dengan baik serta dapat mereka laksanakan karena didukung dengan adanya masker dan hand sanitizer yang bisa langsung digunakan oleh masyarakat.

\section{SIMPULAN}

Kesimpulan yang didapatkan setelah dilakukannya pengabdian kepada masyarakat di Mesjid Miftahul Medina Lingkungan Salabulo Kelurahan Tande Timur Kecamatan Banggae Timur Kabupaten Majene Provinsi Sulawesi Barat bahwa sasaran responden pengabmas yang menjadi sasaran yaitu para anak-anak, orang dewasa dan lansia. Sehingga segala hal ini memiliki sangkut paut antar satu sama lain mengenai pengetahuan tentang COVID-19, penggunaan masker, menjaga jarak, penggunaan alat dispenser hand sanitizer.

Fakta yang ditemukan dilapangan bahwa masyarakat sangat antusias dalam mengikuti kegiatan pengabdian kepada masyarakat ini, hal ini dibuktikan dengan adanya peningkatan kesadaran masyarakat dalam menggunakan masker, selalu menjaga jarak, dan penggunaan hand sanitizer.

Saran bagi para anak-anak, orang dewasa dan lansia di masa pandemic COVID-19 ini sekiranya selalu memperhatikan penggunaan masker, menjaga jarak, dan penggunaan alat dispenser hand sanitizer agar tetap ditegakkan. Saran bagi tenaga kesehatan agar selalu memfasilitasi dalam menjaga protocol kesehatan agar tidak terjadi penularan penyakit COVID-19.

\section{Ucapan Terima Kasih}

Ucapan terimakasih kami haturkan kepada Yayasan Pendidikan Nani Hasanuddin Makassar dan Universitas Sulawesi Barat yang telah memberikan support dan tidak lupa pula 
kami haturkan terimakasih pula kepada seluruh jajaran yang ada di STIKES Nani Hasanuddin Makassar dan Universitas Sulawesi Barat. Adapun kami sampaikan ucapan terimakasih pula kepada seluruh pihak yang telah membantu dalam penyusunan ini hingga selesai.

\section{Daftar Pustaka}

Annisa. 2020. Jokowi: Kebijakan Sekolah di Rumah Dibantu Google hingga Microsoft. Tirto.id. URL https://tirto.id/jokowi-kebijakan-sekolah-di-rumah-dibantu-googlehingga-microsoft-eFtV

Dian. 2020. 5 Cara mencegah Virus Corona yang Disarankan Kemenkes RI dan WHO. SehatQ. URL https://www.sehatq.com/artikel/5-cara-mencegah-penyebaran-viruscorona-yang-disarankan-kemenkes-ri

Gustini, G. Wartana, I. K., dan Elmiyanti, N. K. (2021). Pembagian Masker kepada Masyarakat sebagai Upaya Pencegahan Penyebaran Covid-19. Jurnal Pengabdian Masyarakat Lentora; Vol. 1, No. 1. doi : http://jurnal.poltekkespalu.ac.id/index.php/jpml/article/view/539/241

Infocorona.go.id. 2021. Info Penanggulangan Covid-19 Kota Makassar. Diakses pada tanggal 22 April 2021 yang diakses dari website https://infocorona.makassar.go.id/

Irmayani, Bangun, S. M. Br., Parinduri, A. I., dan Octavariny, R. (2021). Edukasi tentang Penerapan Protokol Kesehatan dalam Upaya Pencegahan Covid-19 di Kabupaten Serdang Bedagai Provinsi Sumatera Utara. Jurnal Pengmas Kestra (JPK). Vol. 1. No. 1. Edisi Juli 2020. Diakses pada tanggal 22 April 2021 yang diakses dari website https://ejournal.medistra.ac.id/index.php/JPK/article/view/559/282

Isdairi, Anwar, H. (2021). Kepatuhan Masyarakat dalam Menerapkan Social Distancing untuk Mencegah Penyebaran Virus Covid-19 di Kabupaten Sambas. Jurnal Ilmu Sosial dan Humaniora (Proyeksi); Vol 26, No. 1. p-ISSN : 2442-3424

Kandari, N. dan Ohorella, F. (2020). Penyuluhan Physical Distancing pada Anak di Panti Asuhan Al Fakri. Jurnal Abdimas Kesehatan Perintis; 2 (1) 2020 : 37-41. doi : https://jurnal.stikesperintis.ac.id/index.php/JAKP

Kresna, A., dan Ahyar, J. (2020). Pengaruh Physical Distancing dan Social Distancing terhadap Kesehatan dalam Pendekatan Linguistik. Jurnal Syntax Transformation; Vol 1, No. 4. p-ISSN : 2721-3854

Lette, A. R., Lemaking, V. B., Feoh, F. T., Muskananfola, I. L., Selly, J. B., Barimbing, M. A., Hurek, R. K. K., dan Dion, Y. (2021). Pembagian Masker dan Vitamin C dalam Upaya Pencegahan Penularan Covid-19 pada Pedagang di Pasar Oesao-Kabupaten Kupang. Jurnal Pengabdian Kepada Masyarakat Indonesia (JPKMI); Vol. 2, No.1. doi : http://icsejournal.com/index.php/JPKMI/article/view/120/60

Li, G. et al. (2020). 'Coronavirus Infections and Immune Responses'. Journal of Medical Virology, 92(4), pp. 424-432. doi: 10.1002/jmv.25685.

Lisa, 2020. Surat Edaran Walikota Medan. Twitter Pemko Medan.

Mariroh, F., Racheshi, A. R., Putri, E., Rohman, N. A., Widiyasari, W., Ma'rufi, I. (2020). Evaluasi Penerapan Protokol Kesehatan di Kampung Tangguh Semeru Perumahan Mastrip Kabupaten Jember. Multidisciplinary Journal; Volume 3, Nomor 1. Doi : https://jurnal.unej.ac.id/index.php/multijournal

Masrul, Abdillah, L. A., Tasnim, Simarmata, J., Daud, Sulaiman, O. K., Prianto, C., Iqbal, M., Purnomo, A., Febrianty, Saputra, D. H., Purba, D. W., Vinolina, N. S., Napitupulu, D., Soetijono, I. K., Ramadhani, Y. R., Jamaludin, Sari, D. C., Rahmadana, R. M. M. F., Hastuti, P., Jamaludin, Faried, A. I. (2020). Pandemik COVID-19: Persoalan dan Refleksi di Indonesia. Yayasan Kita Menulis : Surabaya. 
Nuraeni, I., Bachtiar, R. A., Karimah, I., Hadiningsih, N., Setiawati, D., Saragih, M. (2021). Pencegahan Covid-19 melalui Sosialisasi Penggunaan dan Pembagian Masker di Kota Tasikmalaya dan Kabupaten Tasikmalaya. Jurnal Pengabdian pada Masyarakat Literasi. e-ISSN 2775-3301

Satuan Tugas Penanganan Covid-19. 2021. Analisis Data Covid-19 Indonesia (Update Per 11 April 2021). Diakses pada tanggal 22 April 2021 yang diakses dari website https://covid19.go.id/berita/analisis-data-covid-19-indonesia-update-11-april-2021

WHO. 2021. Coronavirus Disease (Covid-19) pandemic. Diakses pada tanggal 22 April 2021 yang diakses dari website https://www.who.int/emergencies/diseases/novelcoronavirus-2019

WHO. (2020a). Naming the Coronavirus Disease (COVID-19) and the Virus that Causes It. Available at : http://www.who.int/emergencies/diseases/novel-coronavirus2019/technical-guidance/naming-the-coronavirus-disease-(covid-19)-and-the-virusthat-causes-it (Accessed : 14 April 2020).

WHO. (2020b). WHO Director-General's Opening Remarks at the Media Briefing on 2019$n C o V$ on Februari 2020. Available at : http://www.who.int/dg/speeches/detail/whodirector-general-s-remarks-at-the-media-briefing-on-2019-ncov-on-11-february-2020. 